\title{
Fermentation of dietary fibre components in the rat intestinal tract
}

\author{
BY MARGARETA NYMAN AND NILS-GEORG ASP \\ Department of Food Chemistry, Chemical Centre, University of Lund, Lund, Sweden
}

(Received 16 July 1981 - Accepted 15 September 1981)

\begin{abstract}
1. The fermentative breakdown of dietary fibre from various sources in the intestinal tract was studied using rat balance experiments and gas-liquid chromatrographic analysis of dietary fibre monomers in feed and faeces.

2. On a basal diet with $690 \mathrm{~g}$ maize starch $/ \mathrm{kg}$ but no added fibre, small but detectable amounts of polymeric glucose, rhamnose, arabinose, xylose, galactose, mannose and uronic acids, i.e. sugars occurring in dietary fibre, were excreted in faeces.

3. Dietary fibre in wheat bran was rather resistant to fermentation; $63 \%$ was recovered in the faeces. Guar gum, on the other hand, was almost completely fermented, whereas 19 and $25 \%$ of the uronic acids in low and high methoxylated pectin respectively, were excreted in faeces. The various constituents of sugar-beet dietary fibre (approximately equal amounts of arabinose-based hemicellulose, pectin and non-starch glucan (cellulose)) showed quite variable availability for micro-organisms in that $6-12 \%$ of the arabinose, $17-25 \%$ of the uronic acids, and $52-58 \%$ of the cellulose were recovered in the faeces.

4. Faecal nitrogen excretion increased on addition of any one of the dietary fibre preparations studied, resulting in decreased true and apparent protein digestibility values.

5. The faecal dry weight increment was most pronounced when feeding bran and could then almost be accounted for by the remaining fibre and by protein. The less-prominent bulking effect of guar gum and pectins, that were much more extensively fermented, could be only partly explained by dietary fibre and protein.
\end{abstract}

Dietary fibre is by definition (Trowell et al. 1976) resistant to the digestive enzymes in the gastrointestinal tract. The microflora of the large intestine, however, is able to ferment partly the dietary fibre constituents. The extent of fermentation is quite variable between various types of dietary fibre. Thus lignin and also cellulose are highly resistant whereas pectin, guar gum and to some extent hemicelluloses are reported to be easily fermented. (Booth et al. 1963; Yang et al. 1969; Cummings et al. 1979; Dintzis et al. 1979; Gramstorff Fetzer et al. 1979; Heller et al. 1980).

The extent of fermentation of dietary fibre is important for its physiological effects. Thus, easily-fermented types of fibre, such as pectin, have poor bulking capacity. (Cummings et al. 1978). The very good bulking effect of wheat bran can be explained by its relative resistance to fermentation, leaving a substantial amount of water binding fibre also in the distal colon.

Since energy substrate is the limiting factor in colonic bacterial growth (Mason \& Palmer, 1973 ) it is probably also important that a certain proportion of the dietary fibre is fermentable, thus providing energy for the bacterial growth. An increased bacterial mass contributes to the bulking effect of bran and is relatively more important for that of more easily-fermented types of fibre, for example cabbage (Stephen \& Cummings, 1980).

It is still an open question whether fermentable dietary fibre can be utilized as a source of energy. Bond \& Levitt (1976) have shown that lactic acid can be absorbed from the human colon, and Conrad et al. (1958) showed that ${ }^{14} \mathrm{C}$ from labelled soya-bean cellulose fed to rats was found in the expired carbon dioxide as well as in carcass and urine.

Inhibition of mineral absorption by dietary fibre can also be expected to depend partly on the extent of bacterial breakdown, since especially calcium might be absorbed from the colon if released there from binding dietary fibre (James et al. 1978).

The present study was undertaken to provide detailed information on the extent of 
fermentation in the rat intestine of various dietary fibre constituents in wheat bran, guar gum, two pectins with different extents of methoxylation, and sugar-beet fibre. The effect of these types of dietary fibre on nitrogen absorption and utilization was also studied.

\section{MATERIALS AND METHODS}

\section{Dietary fibre preparations}

Coarse wheat bran (Kungsörnen, Sweden) was milled to particle size less than $0.4 \mathrm{~mm}$. Guar gum and pectin with low $(37 \%)$ and high $(74 \%)$ extents of methoxylation were obtained from the Copenhagen Pectin Factory Ltd, Skensved, Denmark. Two dietary-fibre-rich preparations from sugar-beet pulp were obtained from the Swedish Sugar Company. These were also milled to a particle size less than $0.4 \mathrm{~mm}$. The two preparations differed in that one of them (half soluble) was treated with hot water to increase the solubility of pectins.

\section{Animals}

Male Sprague-Dawley rats with initial weight 75-80 g were used. The rats were randomly divided into groups of five. They were kept individually in metabolism cages in an air-conditioned room maintained at $23^{\circ}$ and $50-60 \%$ relative humidity. The food intake was restricted to $10 \mathrm{~g}$ dry weight/d. Water was provided ad lib. Following a $4 \mathrm{~d}$ adaptation period, feed residues, urine and faeces were collected during a $5 \mathrm{~d}$ balance period. Urine was collected in sulphuric acid $(20 \mathrm{ml} / \mathrm{l})$ and analysed for N. Faeces were removed every day and frozen at $-20^{\circ}$. They were then lyophilized, weighed and milled to particle size less than $0.4 \mathrm{~mm}$. $\mathrm{N}$ and carbohydrate analyses were then performed.

\section{Diets}

A basal diet was prepared as described in Table 1 . Casein, $100 \mathrm{~g} / \mathrm{kg}$, was used as source of protein and maize starch was the main carbohydrate. No dietary fibre was included in the basal diet. In the experimental diets the dietary fibre preparations were substituted for maize starch with the following concentrations $(\mathrm{g} / \mathrm{kg})$ : wheat bran 100 , guar gum 100 , high-methoxyl pectin 93, low-methoxyl pectin 94, sugar-beet fibre 100.

\section{Analytic methods}

Dietary fibre. The total dietary fibre content (sum of insoluble and soluble constituents) was assayed gravimetrically after digestion with physiological enzymes as described by N-G. Asp, H. Hallmer, C-G. Johansson and M. Siljeström (unpublished results).

Dietary fibre composition in the feed and in faeces was assayed by gas-liquid chromatographic determination of neutral sugars as their alditol acetates (Sawardeker et al. 1965). Uronic acids were determined using a decarboxylation method (Bylund \& Donetzhuber, 1968). Lignin was determined as Klason lignin, i.e. the residue insoluble in $\mathrm{H}_{2} \mathrm{SO}_{4}(720 \mathrm{ml} / 1)$. Conditions for hydrolysis and other details were as described by Theander \& $\AA$ man (1979).

All dietary fibre components are expressed as polysaccharides, i.e. values obtained with monosaccharides as standards are corrected by multiplication by the factor 0.9 .

$N$ determination. Food components, dietary fibre preparations, urine and faeces were analysed for total $\mathrm{N}$ by the Kjeldahl method using concentrated $\mathrm{H}_{2} \mathrm{SO}_{4}$ at $400^{\circ}$ with selenium as catalyst (Tecator Kjeltec equipment). Crude protein was calculated as $\mathrm{N} \times 6.25$.

Calculation of digestibility and biological value. True digestibility and biological value were calculated using the Thomas-Mitchell equations (Eggum, 1973). Correction factors for endogenous urinary $\mathrm{N}$ and metabolic faecal $\mathrm{N}$ were determined in separate experiments using $40 \mathrm{~g}$ egg protein and $50 \mathrm{~g}$ cellulose $/ \mathrm{kg}$ diet. Apparent digestibility was calculated as $\left(N_{i}-N_{f}\right) / N_{i}$ where $N_{i}$ is the $N$ intake and $N_{f}$ is the $N$ in faeces.

Statistical evaluation. Student's $t$ test (two-tailed) was used. 
Table 1. Components used in the basal diet mixture $(\mathrm{g} / \mathrm{kg})$

\begin{tabular}{lcc}
\hline \multicolumn{1}{c}{ Component } & & \multicolumn{1}{c}{ Source } \\
\hline Casein ANRC 30 M & 100 & $\begin{array}{l}\text { Humko Sheffield Chemicals, } \\
\text { New York, USA }\end{array}$ \\
Sucrose & 100 & Swedish Sugar Company AB \\
Maize starch & 692 & AB Risenta, Sweden \\
Maize oil & 50 \\
Mineral mixture* & 48 & \\
Vitamin mixture $\dagger$ & 8 & $\begin{array}{l}\text { Purchashed through } \\
\text { hospital pharmacy }\end{array}$ \\
Choline chloride & 2 & \\
\hline \hline
\end{tabular}

* Contained (g): $\mathrm{CuSO}_{4} \cdot 5 \mathrm{H}_{2} \mathrm{O} 8 \cdot 6, \mathrm{ZnSO}_{4} \cdot 7 \mathrm{H}_{2} \mathrm{O} 32 \cdot 0, \mathrm{KH}_{3} \mathrm{PO}_{4} 7780, \mathrm{NaH}_{2} \mathrm{PO}_{4} \cdot 2 \mathrm{H}_{2} \mathrm{O} 4024, \mathrm{CaCO}_{3} 7600, \mathrm{KI}$ $1 \cdot 6, \mathrm{MgSO}_{4} \cdot 7 \mathrm{H}_{2} \mathrm{O} 2000, \mathrm{FeSO}_{4} \cdot 7 \mathrm{H}_{2} \mathrm{O} 180, \mathrm{MnSO}_{4} \cdot \mathrm{H}_{2} \mathrm{O} 80, \mathrm{CoCl}_{2} 0 \cdot 46, \mathrm{NaCl} 2382$.

$\dagger$ Contained $(\mathrm{g})$ : menadione $2 \cdot 5$, thiamin hydrochloride 10.0 , riboflavin $10 \cdot 0$, pyridoxin hydrochloride $5 \cdot 0$, calcium pantothenate $25 \cdot 0$, nicotinic acid $25 \cdot 0$, folic acid $1 \cdot 0$, inositol $50 \cdot 0$, p-aminobenzoic acid $5 \cdot 0$, biotin $0 \cdot 2$, vitamin $B_{12}$, cyanocobalamin 0.015 , vitamin A 0.86 , vitamin D 0.025, vitamin E 100, wheat starch 3765 .

\section{RESULTS AND DISCUSSION}

\section{Dietary fibre composition and degradation in the rat intestinal tract}

Basal diet. The maize starch used as the carbohydrate base in the diets contained $8 \mathrm{~g}$ dietary fibre $/ \mathrm{kg}$ as measured by the enzymic gravimetric method described previously. Gaschromatographic analysis of monomers after acid-hydrolysis of this fibre showed mainly glucose but also traces of rhamnose, arabinose, xylose, mannose and galactose. Thus, the small amount of dietary fibre in the maize starch was mainly in vitro indigestible starch or other glucans and to a smaller extent hemicellulose impurities.

Table 2 shows intake and faecal excretion of dietary fibre monomers on the basal diet containing $692 \mathrm{~g}$ maize starch $/ \mathrm{kg}$ but no added dietary fibre. The faecal excretion was lower than the intake for most monomers but higher than the intake for rhamnose. A small amount of uronic acids was detected in the faeces but not in the diet.

It cannot be settled from our experiments whether the faecal excretion of dietary fibre monomers is due to remnants of the fibre in the maize starch resistant to bacterial degradation, endogenous polysaccharide excretion, or bacterial polysaccharide synthesis. The levels, however, were comparatively very small and therefore not essential to the interpretation of the further results, even if this basal excretion of dietary fibre monomers might vary with the diet.

Wheat bran. The wheat bran contained $498 \mathrm{~g}$ dietary fibre (moisture free basis) $/ \mathrm{kg}$ as determined by the enzymic gravimetric method, and of this $27 \mathrm{~g} / \mathrm{kg}$ was soluble. Table 3 shows the dietary fibre composition. As expected, the main monomer components were arabinose, xylose and glucose. Small amounts of mannose, galactose and uronic acids were detected as well. The Klason lignin content was $99 \mathrm{~g} / \mathrm{kg}$.

The faeces contained small amounts of rhamnose in addition to those present in the basal diet, as was the situation after feeding the basal diet. The faecal recovery of arabinose- and xylose-based fibre was 57 and $46 \%$ of the intake, respectively. These values are in good agreement with those reported by Bertrand et al. (1981). The glucose-based fibre, i.e. the non-starch glucans, seemed somewhat more resistant to fermentation, but after correction for the polyglucose excreted on the basal diet the extent of fermentation was similar to that of pentosans, as shown in Table 3.

Lignin seemed resistant to bacterial degradation, which is in agreement with earlier studies (Gordon, 1978; Bertrand et al. 1981). 
Table 2. Faecal excretion of carbohydrates by rats given the basal diet

(Mean values and standard deviations)

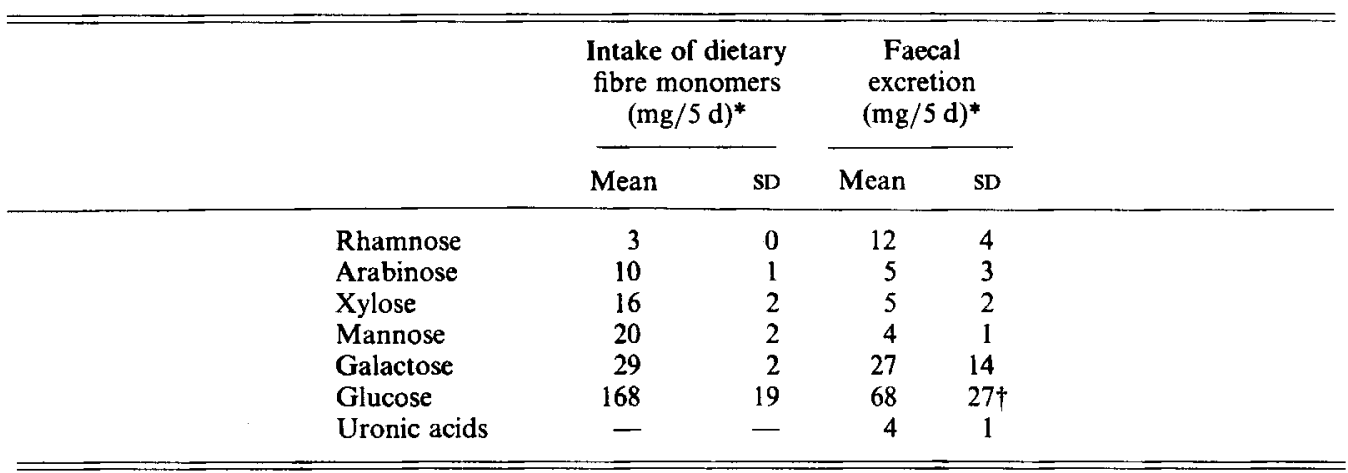

- As anhydro sugars.

$\dagger$ Corrected for free glucose (approximately $3 \mathrm{mg} / 5 \mathrm{~d}$ ).

Table 3. Composition and faecal recovery of dietary fibre in wheat bran (Mean values and standard deviations)

\begin{tabular}{|c|c|c|c|c|c|c|c|c|c|}
\hline & \multirow{3}{*}{$\begin{array}{l}\text { Composition of } \\
\text { dietary fibre } \\
\text { (g/kg dry matter) }\end{array}$} & & & \multicolumn{6}{|c|}{ Faecal excretion } \\
\hline & & \multicolumn{2}{|c|}{$\begin{array}{c}\text { Intake } \\
(\mathrm{mg} / \mathrm{sd})\end{array}$} & \multicolumn{2}{|c|}{$\mathrm{mg} / \mathrm{sd}$} & \multicolumn{2}{|c|}{$\%$ of intake } & \multicolumn{2}{|c|}{$\begin{array}{c}\text { Corrected for } \\
\text { basal excretion } \|\end{array}$} \\
\hline & & Mean & SD & Mean & SD & Mean & SD & Mean & SD \\
\hline Rhamnose & - & $\ldots$ & - & 17 & 4 & & & & \\
\hline Arabinose & 99 & 489 & 2 & 279 & 22 & 57 & 4 & 57 & 4 \\
\hline Xylose & 143 & 707 & 2 & 323 & 17 & 46 & 2 & 45 & 2 \\
\hline Mannose & 4 & 18 & 0 & 13 & 1 & 72 & 7 & 50 & 7 \\
\hline Galactose & 10 & 50 & 0 & 42 & 6 & 83 & 13 & 29 & 13 \\
\hline Glucose & 131 & 647 & 2 & 395 & $30^{*}$ & 61 & 5 & 51 & 5 \\
\hline Uronic acids & 5 & 25 & 0 & \multicolumn{2}{|c|}{$14 \dagger$} & \multicolumn{2}{|c|}{56} & \multirow{2}{*}{\multicolumn{2}{|c|}{40}} \\
\hline Klasin lignin & 99 & 493 & 2 & 450 & 65 & 91 & 13 & & \\
\hline Total & 491 & 2430 & 8 & 1520 & 50 & 63 & 2 & 58 & 2 \\
\hline
\end{tabular}

Wheat bran fibre was thus rather resistant to fermenation in the large bowel, $63 \%$ of the total fibre being recovered in the faeces. The bulking effect of bran can largely be explained by remaining dietary fibre. Thus, $75 \%$ of the faecal dry weight increment was due to remaining dietary fibre as shown in Table 10. This is in agreement with results from human studies (Stephen \& Cummings, 1980).

Guar gum. This gel-forming type of dietary fibre is a rather pure galactomannan with (mmol/mol) 525 mannose and 311 galactose (Table 4). Our preparation also contained small amounts of arabinose, glucose and uronic acids.

The galactomannan of guar gum was fermented almost quantitatively. Thus, only approximately $1 \%$ of the mannose and $4 \%$ of the galactose appeared in the faeces. The minor components were also fermented almost completely. 
Table 4. Composition and faecal recovery of dietary fibre in guar gum (Mean values and standard deviations)

\begin{tabular}{|c|c|c|c|c|c|c|c|c|c|}
\hline & \multirow{3}{*}{$\begin{array}{l}\text { Composition of } \\
\text { dietary fibre } \\
\text { (g/kg dry matter) }\end{array}$} & & & \multicolumn{6}{|c|}{ Faecal excretion } \\
\hline & & \multicolumn{2}{|c|}{$\begin{array}{c}\text { Intake } \\
(\mathrm{mg} / 5 \mathrm{~d})\end{array}$} & \multicolumn{2}{|c|}{$\mathrm{mg} / 5 \mathrm{~d}$} & \multicolumn{2}{|c|}{$\%$ of intake } & \multicolumn{2}{|c|}{$\begin{array}{l}\text { Corrected for } \\
\text { basal excretion }\end{array}$} \\
\hline & & Mean & SD & Mean & SD & Mean & SD & Mean & SD \\
\hline Rhamnose & 5 & 18 & 2 & 24 & 10 & 130 & 41 & 64 & 46 \\
\hline Arabinose & 19 & 73 & 7 & 3 & 0.5 & 74 & 0.4 & 0 & \\
\hline Xylose & 3 & 12 & 1 & 3 & 0.7 & 26 & 9 & 0 & \\
\hline Mannose & 525 & 2070 & 190 & 18 & 12 & 1 & 0.5 & 0.6 & 0.5 \\
\hline Galactose & 311 & 1230 & 110 & 48 & 21 & 4 & 1 & 2 & 1 \\
\hline Glucose & 31 & 123 & 11 & 33 & $13^{*}$ & 26 & 10 & 0 & \\
\hline Uronic acids & 15 & 59 & 6 & 9 & 5 & 15 & 8 & 8 & 8 \\
\hline Klason lignin & - & - & - & - & -- & - & - & - & - \\
\hline Total & 909 & 3580 & 320 & 137 & 54 & 4 & 1 & 1 & 1 \\
\hline
\end{tabular}

* Corrected for free glucose (approximately $3 \mathrm{mg} / 5 \mathrm{~d}$ ).

$\dagger$ For details, see Table 2.

Table 5. Composition and faecal recovery of dietary fibre in low-methoxyl pectin (extent of methoxylation $37 \%$ )

(Mean values and standard deviations)

\begin{tabular}{|c|c|c|c|c|c|c|c|}
\hline & \multirow{3}{*}{$\begin{array}{c}\text { Composition of } \\
\text { dietary fibre } \\
\text { (g/kg dry matter) }\end{array}$} & \multirow{2}{*}{\multicolumn{2}{|c|}{$\begin{array}{c}\text { Intake } \\
(\mathrm{mg} / 5 \mathrm{~d})\end{array}$}} & \multicolumn{4}{|c|}{ Faecal excretion } \\
\hline & & & & \multicolumn{2}{|c|}{$\mathrm{mg} / 5 \mathrm{~d} \dagger$} & \multicolumn{2}{|c|}{$\%$ of intake } \\
\hline & & Mean & SD & Mean & SD & Mean & SD \\
\hline Rhamnose & 7 & 26 & 4 & 14 & & & \\
\hline Arabinose & 2 & 9 & 1 & - & & & \\
\hline Xylose & 1 & 5 & 1 & - & & & \\
\hline Mannose & 1 & 3 & 0 & - & & & \\
\hline Galactose & 30 & 115 & 14 & 22 & & & \\
\hline Glucose & 4 & 14 & 2 & $64^{*}$ & & & \\
\hline Uronic acids & 873 & 3370 & 430 & 650 & 455 & 19 & 12 \\
\hline
\end{tabular}

* Corrected for free glucose (approximately $3 \mathrm{mg} / 5 \mathrm{~d}$ ).

$\dagger$ The aldoses are analysed in one rat only.

In spite of the almost complete fermentation of guar gum, this fibre had a certain bulking effect (Table 10). Obviously, this was due to increased faecal losses of non-fibre material (see p. 364).

Pectin. The low-and high-methoxyl preparations were rather pure uronic acid polymers with small amounts of rhamnose and galactose, and in the high-methoxyl pectin also arabinose (Tables 5 and 6 ). The mean faecal recovery of uronic acids was $19 \%$ for the low-methoxyl pectin and $25 \%$ for the high-methoxyl pectin. Thus, the low-methoxyl pectin seemed to be fermented more efficiently, which is not in agreement with the study of Gilmore (1965). However, in our study there was a considerable variation between different rats and therefore the difference was not statistically significant. The excretion of the minor dietary fibre monomers was approximately the same as on the basal diet. 
Table 6. Composition and faecal recovery of dietary fibre in high-methoxyl pectin (extent of methoxylation $74 \%$ )

(Mean values and standard deviations)

\begin{tabular}{|c|c|c|c|c|c|c|c|}
\hline & \multirow{3}{*}{$\begin{array}{l}\text { Composition of } \\
\text { dietary fibre } \\
\text { (g/kg dry matter) }\end{array}$} & \multirow{2}{*}{\multicolumn{2}{|c|}{$\begin{array}{c}\text { Intake } \\
(\mathrm{mg} / 5 \mathrm{~d})\end{array}$}} & \multicolumn{4}{|c|}{ Faecal excretion } \\
\hline & & & & \multicolumn{2}{|c|}{$\mathrm{mg} / 5 \mathrm{~d} \dagger$} & \multicolumn{2}{|c|}{$\%$ of intake } \\
\hline & & Mean & SD & Mean & SD & Mean & SD \\
\hline Rhamnose & 9 & 35 & 4 & 49 & & & \\
\hline Arabinose & 35 & 137 & 15 & - & & & \\
\hline Xylose & 2 & 9 & 1 & 5 & & & \\
\hline Mannose & 1 & 3 & 0 & 15 & & & \\
\hline Galactose & 41 & 159 & 17 & 44 & & & \\
\hline Glucose & 5 & 19 & 2 & $75^{*}$ & & & \\
\hline Uronic acids & 796 & 3330 & 510 & 803 & 689 & 25 & 20 \\
\hline
\end{tabular}

- Corrected for free glucose (approximately $3 \mathrm{mg} / 5 \mathrm{~d}$ ).

$\dagger$ The aldoses are analysed in one rat only.

Table 7. Composition and faecal recovery of dietary fibre in half-soluble beet fibre (Mean values and standard deviations)

\begin{tabular}{|c|c|c|c|c|c|c|c|c|c|}
\hline & \multirow{3}{*}{$\begin{array}{l}\text { Composition of } \\
\text { dietary fibre } \\
\text { (g/kg dry matter) }\end{array}$} & & & \multicolumn{6}{|c|}{ Faecal excretion } \\
\hline & & \multicolumn{2}{|c|}{$\begin{array}{c}\text { Intake } \\
(\mathrm{mg} / 5 \mathrm{~d})\end{array}$} & \multicolumn{2}{|c|}{$\mathrm{mg} / 5 \mathrm{~d}$} & \multicolumn{2}{|c|}{$\%$ of intake } & \multicolumn{2}{|c|}{$\begin{array}{c}\text { Corrected for } \\
\text { basal excretion }\end{array}$} \\
\hline & & Mean & SD & Mean & SD & Mean & SD & Mean & SD \\
\hline Rhamnose & 13 & 58 & 8 & 29 & 11 & 49 & 14 & 28 & 16 \\
\hline Arabinose & 172 & 780 & 109 & 46 & 27 & 6 & 3 & 5 & 3 \\
\hline Xylose & 11 & 49 & 7 & 28 & 5 & 57 & 11 & 47 & 10 \\
\hline Mannose & 8 & 38 & 5 & 23 & 10 & 59 & 18 & 49 & 20 \\
\hline Galactose & 41 & 184 & 26 & 42 & 15 & 23 & 7 & 9 & 6 \\
\hline Glucose & 185 & 836 & 117 & 451 & $284^{*}$ & 52 & 29 & 43 & 30 \\
\hline Uronic acids & 228 & 1030 & 140 & 182 & 83 & 17 & 6 & 17 & 6 \\
\hline Klason lignin & 36 & 163 & 23 & 176 & 50 & 107 & 21 & & \\
\hline Total & 694 & 3140 & 440 & 976 & 463 & 30 & 12 & 26 & 12 \\
\hline
\end{tabular}

* Corrected for free glucose (approximately $3 \mathrm{mg} / 5 \mathrm{~d}$ ).

† For details, see Table 2.

Sugar-beet fibre. The half-soluble and ordinary sugar-beet-fibre preparations studied had a total dietary fibre content of 743 and $767 \mathrm{~g} / \mathrm{kg}$ respectively. Of this, the soluble fraction of dietary fibre constituted 254 and $153 \mathrm{~g} / \mathrm{kg}$ respectively. As shown in Tables 7 and 8 , the sugar-beet fibre consists of mainly arabinose-based hemicellulose, non-starch glucans (cellulose) and pectin. The two preparations studied had similar monomeric composition.

The extent of fermentation of the various dietary fibre components was highly variable. Thus, the mean faecal recoveries $(\%)$ were: arabinose $6-12$, glucose $52-58$, uronic acids 17-25. The half-soluble preparation tended to be somewhat more fermented but the difference was not statistically significant. Lignin was nearly completely undegraded. 
Table 8. Composition and faecal recovery of dietary fibre in ordinary beet fibre (Mean values and standard deviations)

\begin{tabular}{|c|c|c|c|c|c|c|c|c|c|}
\hline & \multirow{3}{*}{$\begin{array}{l}\text { Composition of } \\
\text { dietary fibre } \\
\text { (g/kg dry matter) }\end{array}$} & \multirow{2}{*}{\multicolumn{2}{|c|}{$\begin{array}{l}\text { Intake } \\
\mathrm{mg} / 5 \mathrm{~d}\end{array}$}} & \multicolumn{5}{|c|}{ Faecal excretion } & \\
\hline & & & & \multicolumn{2}{|c|}{$\mathrm{mg} / 5 \mathrm{~d}$} & \multicolumn{2}{|c|}{$\%$ of intake } & \multicolumn{2}{|c|}{$\begin{array}{l}\text { Corrected for } \\
\text { basal excretion } \dagger\end{array}$} \\
\hline & & Mean & SD & Mean & SD & Mean & SD & Mean & SD \\
\hline Rhamnose & 13 & 66 & 2 & 33 & 8 & 50 & 13 & 32 & 13 \\
\hline Arabinose & 211 & 1060 & 27 & 127 & 87 & 12 & 8 & 12 & 8 \\
\hline Xylose & 11 & 53 & 1 & 37 & 5 & 70 & 9 & 60 & 9 \\
\hline Mannose & 8 & 40 & 1 & 22 & 9 & 55 & 22 & 44 & 22 \\
\hline Galactose & 42 & 204 & 5 & 55 & 22 & 27 & 11 & 14 & 10 \\
\hline Glucose & 191 & 933 & 24 & 538 & $182^{*}$ & 58 & 19 & 50 & 19 \\
\hline Uronic acids & 207 & 1010 & 30 & 247 & 116 & 25 & 11 & 24 & 11 \\
\hline Klason lignin & 62 & 303 & 8 & 254 & 93 & 84 & 30 & & \\
\hline Total & 745 & 3670 & 90 & 1310 & 340 & 36 & 9 & 32 & 9 \\
\hline
\end{tabular}

* Corrected for free glucose (approximately $3 \mathrm{mg} / 5 \mathrm{~d}$ ).

$\uparrow$ For details, see Table 2.

Table 9. Effect of various dietary fibre preparations on protein utilization by rats (Mean values and standard deviations)

\begin{tabular}{|c|c|c|c|c|c|c|c|c|c|c|}
\hline \multirow{2}{*}{$\begin{array}{l}\text { Dietary fibre } \\
\text { source }\end{array}$} & \multicolumn{2}{|c|}{$\begin{array}{c}\text { Additional } N \\
\text { from dietary } \\
\text { fibre preparations } \\
(\mathrm{mg} / 5 \mathrm{~d})\end{array}$} & \multicolumn{2}{|c|}{$\begin{array}{l}\text { Faecal N } \\
(\mathrm{mg} / 5 \mathrm{~d})\end{array}$} & \multicolumn{2}{|c|}{$\begin{array}{c}\text { True } \\
\text { digestibility }\end{array}$} & \multicolumn{2}{|c|}{$\begin{array}{c}\text { Apparent } \\
\text { digestibility }\end{array}$} & \multicolumn{2}{|c|}{$\begin{array}{l}\text { Biological } \\
\text { value }\end{array}$} \\
\hline & Mean & SD & Mean & SD & Mean & SD & Mean & SD & Mean & SD \\
\hline Basal diet & - & - & $52 \cdot 4$ & $21 \cdot 5$ & 1.018 & 0.026 & 0.928 & 0.026 & 0.829 & 0.044 \\
\hline Wheat bran & 114.4 & 0.5 & $98 \cdot 4$ & $21 \cdot 9 * *$ & 0.962 & $0.028^{*}$ & 0.874 & $0.026^{\star}$ & 0.771 & 0.051 \\
\hline Guar gum & $8 \cdot 3$ & 0.8 & $134 \cdot 2$ & $38 \cdot 4^{* * *}$ & 0.872 & $0.051^{* * *}$ & 0.783 & $0.052^{* * *}$ & 0.843 & 0.039 \\
\hline $\begin{array}{l}\text { Low-methoxyl } \dagger \\
\text { pectin }\end{array}$ & - & - & 119.4 & $13 \cdot 7^{* * *}$ & 0.911 & $0.023^{* * *}$ & 0.819 & $0.023^{* * *}$ & 0.799 & 0.050 \\
\hline $\begin{array}{l}\text { High-methoxyl } \\
\text { pectin }\end{array}$ & - & - & 149.9 & $23 \cdot 2^{* * *}$ & 0.869 & $0.022^{* * *}$ & 0.777 & $0.022^{* * *}$ & 0.816 & 0.031 \\
\hline $\begin{array}{l}\text { Half-soluble } \\
\text { sugar-beet } \\
\text { fibre }\end{array}$ & 90.6 & $12 \cdot 7$ & $131 \cdot 4$ & $17 \cdot 8 * * *$ & 0.910 & $0.033^{* * *}$ & 0.830 & $0.033^{* * *}$ & 0.744 & $0.043^{*}$ \\
\hline $\begin{array}{l}\text { Ordinary sugar- - } \\
\text { beet fibre }\end{array}$ & $97 \cdot 9$ & $2 \cdot 5$ & $131 \cdot 0$ & $16 \cdot 2 * * *$ & 0.925 & $0.019 * * *$ & 0.846 & $0.019^{* * *}$ & 0.752 & $0.033^{*}$ \\
\hline
\end{tabular}

* $P<0.05$, ** $P<0.01$, *** $P<0.005$.

$\dagger$ Low-methoxyl pectin (extent of methoxylation $37 \%$ ).

$\ddagger$ High-methoxyl pectin (extent of methoxylation $74 \%$ ).

\section{Protein utilization}

Faecal $\mathbf{N}$ excretion increased when the various fibre preparations were added to the basal diet (Table 9). The increase was most pronounced with high-methoxyl pectin, followed by guar gum and the two sugar-beet-fibre preparations. There was, therefore, a decrease in both apparent and true digestibility values. The biological value of the absorbed protein was significantly lowered when the sugar-beet-fibre preparation was added to the basal diet.

Wheat bran and the two sugar-beet-fibre preparations contained significant amounts of 
Table 10. Effect of various dietary fibre preparations on fibre intake and faecal output of rats

(Mean values and standard deviations)

\begin{tabular}{|c|c|c|c|c|c|c|c|c|c|c|c|}
\hline \multirow{3}{*}{$\begin{array}{l}\text { Dietary fibre } \\
\text { source }\end{array}$} & \multicolumn{4}{|c|}{$\begin{array}{l}\text { Dietary fibre intake* } \\
\qquad(\mathrm{g} / 5 \mathrm{~d})\end{array}$} & & & \multicolumn{5}{|c|}{$\begin{array}{l}\text { Faecal dry wt } \\
\qquad(\mathrm{g} / 5 \mathrm{~d})\end{array}$} \\
\hline & \multicolumn{2}{|c|}{$\begin{array}{l}\text { Indigestible } \\
\text { starch }\end{array}$} & \multicolumn{2}{|c|}{$\begin{array}{l}\text { Added } \\
\text { fibre }\end{array}$} & \multicolumn{2}{|c|}{$\begin{array}{l}\text { Faecal wet } \\
\text { wt }(\mathrm{g} / 5 \mathrm{~d})\end{array}$} & \multicolumn{2}{|c|}{ Total } & \multirow{2}{*}{\multicolumn{2}{|c|}{$\begin{array}{c}\text { Dietary } \\
\text { fibre } \\
\text { residue }\end{array}$}} & \multirow{2}{*}{$\begin{array}{l}\text { Protein } \\
\text { increment }\end{array}$} \\
\hline & Mean & SD & Mean & SD & Mean & SD & Mean & SD & & & \\
\hline Basal diet & $0 \cdot 25$ & 0.03 & 0 & & $2 \cdot 1$ & 0.7 & 1.6 & 0.4 & - & - & - \\
\hline Wheat bran & 0.22 & 0.00 & $2 \cdot 43$ & 0.01 & $5 \cdot 3$ & 0.6 & 3.6 & 0.4 & $2 \cdot 0$ & $1 \cdot 5$ & $0 \cdot 3$ \\
\hline Guar gum & 0.18 & 0.02 & $3 \cdot 58$ & 0.32 & 3.9 & 1.0 & $2 \cdot 7$ & $0 \cdot 6$ & $1 \cdot 1$ & 0.1 & 0.5 \\
\hline $\begin{array}{l}\text { Low-methoxyl } \dagger \\
\text { pectin }\end{array}$ & $0 \cdot 19$ & 0.02 & $3 \cdot 37$ & 0.43 & $7 \cdot 0$ & $4 \cdot 3$ & $3 \cdot 4$ & 0.9 & $1 \cdot 8$ & 0.7 & 0.4 \\
\hline $\begin{array}{l}\text { High-methoxyl } \neq \\
\text { pectin }\end{array}$ & $0 \cdot 19$ & 0.02 & $3 \cdot 33$ & 0.51 & $7 \cdot 3$ & $3 \cdot 1$ & $4 \cdot 2$ & 1.5 & $2 \cdot 6$ & $0 \cdot 8$ & 0.6 \\
\hline $\begin{array}{l}\text { Half-soluble } \\
\text { sugar-beet } \\
\text { fibre }\end{array}$ & $0 \cdot 22$ & 0.01 & $3 \cdot 14$ & 0.44 & $5 \cdot 8$ & $2 \cdot 7$ & $3 \cdot 3$ & 0.8 & $1 \cdot 7$ & 1.0 & 0.5 \\
\hline $\begin{array}{l}\text { Ordinary sugar- } \\
\text { beet fibre }\end{array}$ & $0 \cdot 20$ & 0.03 & $3 \cdot 67$ & 0.09 & 8.4 & $2-6$ & $3 \cdot 8$ & 0.6 & $2 \cdot 2$ & $1 \cdot 3$ & 0.5 \\
\hline
\end{tabular}

* The values denote dietary fibre from the different preparations added to the basal diet. The maize starch contained $8 \mathrm{~g}$ indigestible starch $/ \mathrm{kg}$ which is also by definition dietary fibre.

$\dagger$ Low-methoxyl pectin (extent of methoxylation $37 \%$ ).

$\ddagger$ High-methoxyl pectin (extent of methoxylation $74 \%$ ).

protein (Table 9). Thus, the increased faecal $\mathbf{N}$ and decreased true and apparent digestibility when feeding these types of fibre could be due to poor digestibility of the fibre-associated protein. The pectin and guar gum preparations, however, that caused the most prominent increase of faecal $\mathbf{N}$, contained very little or no $\mathbf{N}$. In these instances, therefore, the increase must have been due either to altered metabolic $\mathrm{N}$ loss or to interference with the digestion of dietary protein (casein). The most probable alternative is that the increased faecal $\mathrm{N}$ after feeding dietary fibre-containing diets represents bacterial protein synthesized from simple $\mathrm{N}$ sources, such as urea or ammonia. Whereas energy substrates are regarded as rate limiting for colonic bacterial growth (Mason \& Palmer, 1973), such $\mathrm{N}$ sources are readily available through diffusion across the colonic wall. The lower biological value for diets containing wheat bran or sugar-beet fibre is most probably due to the additional contribution of dietary protein from these dietary fibre preparations. This can be expected to have rather low nutritional value thus decreasing the biological value of the whole diet. However, an inhibition of protein digestion by dietary fibre cannot be excluded from these experiments.

\section{Faecal bulking}

Addition of any one of the dietary fibre preparations caused a significant increase in faecal wet as well as dry weight. In the instance of bran, almost all the increased faecal loss could be accounted for by dietary fibre residues and protein (Table 10). Guar gum, on the other hand, that was almost completely fermented also gave an increased faecal mass that was only partially accounted for by the increased faecal protein. The two pectins also gave a more prominent increase in faecal dry weight than expected from faecal pectin residues and protein. It is well documented that both guar gum and pectin increase faecal fat, which probably accounts for the rest of the faecal dry weight increment after feeding these types of fibre. 


\section{GENERAL DISCUSSION AND CONCLUSIONS}

The present study confirms the great variability in the extent of fermentative breakdown of various kinds of dietary fibre in the intestinal tract. The results are similar to those reported so far from human investigations. Comparative studies, in which the same dietary fibre preparations are tested both in rat and human balance experiments are needed, however, to document the usefulness of this rat experimental model to predict the physiologically-important property of bacterial fermentability exhibited by dietary fibre. Rat experiments could then be used, for instance, to study the effect of processing of fibrous foods in this respect.

The reason for the relative resistance of bran fibre to bacterial degradation is obscure. A simple physical hindrance of bacterial enzyme access to the inner core of bran particles seems unlikely in view of the fact that the bran in our diets was milled to very small particles. Furthermore, Bertrand et al. (1981) showed that chemical delignification did not alter the faecal recovery of dietary fibre from bran.

Extrusion cooking is increasingly used for processing cereal foods. In that process the material undergoes a prominent expansion due to heating at very high pressure and sudden introduction to atmospheric pressure at the end of the process. In a recent study (I. Björck, M. Nyman and N-G. Asp, unpublished results) we found similar proportions of dietary fibre constituents remaining in the faeces when feeding extruded and raw whole-grain wheat flour to rats. It therefore seems more likely that certain chemical bindings in dietary fibre polymers, or between such polymers, and for instance structural proteins, limit the bacterial degradation of certain kinds of dietary fibre. The structural difference between dietary fibre that is fermented and that which is not, needs further investigation.

The sugar-beet-fibre preparations studied contained similar proportions of arabinosebased hemicellulose, pectin and non-starch glucan (cellulose). Interestingly, these different components showed a completely different extent of fermentation. The arabinan was fermented almost quantitatively like the guar gum, the pectin was fermented to approximately the same extent as the purified pectins, and the glucan showed an extent of fermentation very similar to that of bran fibre. This finding provided further evidence that the chemical structure rather than the physical appearance determines the resistance to bacterial breakdown.

Since faecal polysaccharides were hydrolyzed without any previous fractionation it cannot be determined absolutely from our results whether the monosaccharides detected represented dietary fibre residues, bacterial cell-wall polysaccharides, or secreted glucoproteins or glucosaminoglucans. The low monosaccharide levels detected on a practically fibre-free diet, and the fact that feeding easily-fermented dietary fibre like guar gum or pectin did not cause the appearance of faecal sugars other than those present in the fibre, strongly suggest that by far the major part of the faecal sugars were constituents of dietary fibre resistant to bacterial degradation. Studies are in progress to elucidate this point further.

This study was supported by grants from the National Swedish Board of Technical Development, Albert Påhlsson's Foundation, the Swedish Medical Research Council and the Swedish Sugar Company.

Bertrand, D., Brillouet, J. M., Rasper V. F., Bouchet, B. \& Mercier, C. (1981). Cereal Chem. 58, 467.

Bond, J. H. \& Levitt, M. D. (1976). Gastroenterology 70, 1058.

Booth, A. N., Hendrickson, A. \& De Eds, F. (1963). Taxic. appl. Pharmac. 5, 478.

Bylund, M. \& Donetzhuber, A. (1968). Sv. Papperstidn. 15, 505.

Conrad, H. E., Watts, W. R., Iacono, J. M., Kraybill, H. F. \& Friedemann, T. E. (1958). Science, N. Y. $127,1293$. 
Cummings, J. H., Southgate, D. A. T., Branch, W. J., Houston, H., Jenkins, D. J. A. \& James, W. P. T. (1978). Lancet i, 5.

Cummings, J. H., Southgate, D. A. T., Branch, W. J. \& Wiggins, H. S. (1979). Br. J. Nutr. $41,477$.

Dintzis, F. R., Legg, L. M., Deatherage, W. L., Baker, F. I., Inglett, G. E., Jacob, R. A., Reck, S. J., Munoz, J. M., Klevay, L. M., Sandstead, H. H. \& Shuey, W. C. (1979). Cereal Chem. 56, 123.

Eggum, B. O. (1973). Natn. Inst. Anim. Sci., Copenhagen 406.

Gilmore, N. (1965). Effect of 5 percent pectin NF or 5 percent pectin LM upon growth, excretion serum proteins, and mineral contents in liver and kidney tissues of weaning male rats of the Sprague-Dawley strain. PhD thesis, Michigan State University, USA.

Gordon, A. J. (1978). In Topics in Dietary Fiber Research, p. 59 [G. A. Spiller, editor]. New York and London: Plenum Press.

Gramstorff Fetzer, S., Kies, C. \& Fox, H. M. (1979). Cereal Chem. 56, 34.

Heller, S. N., Hackler, L. R., Rivers, J. M., Van Soest, P. J., Roe, D. A., Lewis, B. A. \& Robertson, J. (1980). Am. J. clin. Nutr. 33, 1734.

James, W. P. T., Branch, W. J. \& Southgate, D. A. T. (1978). Lancet i, 638.

Mason, V. C. \& Palmer, R. (1973). Acta Agric. scand. 23, 141.

Sawardeker, J. S., Sloneker, J. H. \& Jeanes, A. (1965). Analyt. Chem. 37, 1602.

Stephen, A. M. \& Cummings, J. H. (1980). Nature, Lond. 284, 283.

Theander, O. \& Åman, P. (1979). Swedish J. agric. Res. 9, 97.

Trowell, H. C., Southgate, D. A. T., Wolever, T. M. S., Leeds, A. R., Gassull, M. A. \& Jenkins, D. A. (1976). Lancet i, 967.

Yang, M.'G., Manoharan, K. \& Young, A. K. (1969). J. Nutr. 97, 260. 